\title{
Overview of Vietnamese Accounting System Since 1975 and the Process of Vietnam's Convergence to IFRS
}

\author{
Nguyen Xuan Hung \\ University of Economics Ho Chi Minh City, Vietnam
}

\begin{abstract}
The development of accounting systems is influenced by socio-economic characteristics at each stage. The paper explores the impact of the characteristics of political institutions at every stage in the development of social economy, which determines the objects using accounting information, as well as the legal accounting system issued so that accounting can meet the demand for accounting information of these objects in Vietnam from 1975 to the present. Based on studies by authors in this period as well as issued accounting documents system, this paper aims to point out the formation and development process of Vietnam accounting system, providing researchers and elaborating agencies with a basis for determining the right development direction of Vietnam accounting in the coming time.
\end{abstract}

Keywords: Vietnam accounting system, accounting integration process, socio-economic characteristics

\section{Introduction}

In every country, the particular characteristics of political institutions affect the economic development of the country and their influence through the formation of social and economic sectors as well as the policy of macro-economic and social management. Therefore, this promotes or restrains economic trade among countries. In parallel with the development of the economy, accounting as a management tool also comes with the socio-economic characteristics. The development of social economy will generate the objects that need to use accounting information. This enables accounting to develop and integrate with regions worldwide. In Vietnam, this will be verified through the development process of accounting since 1975. The Communist Party is the highest authority holding leadership roles in all periods, the Government holds management roles, and the people are sovereign. It is true that Vietnamese Government has the strongest power in enacting legislations as well as managing and regulating industries, the economic field with the legal documents, accounting field is also subject to this administration.

Under these characteristics, we will take a look at the Vietnamese accounting system in recent four decades in subsequent sections.

\section{Period of 1975-1985}

\section{Characteristics of the Political Situation}

After the reunification of North and South Vietnam in April 1975, the political system of Vietnam changed from the systems people's democratic dictatorship to the dictatorship of the proletariat (Ministry of Education and Training, 2009). In terms of overall look, from 1975 to 1989, international relations of Vietnam

Nguyen Xuan Hung, associate professor, vice dean of Accounting School, University of Economics Ho Chi Minh City. Email: hungnx@ueh.edu.vn. 
met with great difficulties, e.g., the ASEAN countries and some other countries embargoed against Vietnam. As a result, foreign relations of Vietnam in that period were done mainly with the socialist countries, especially the Soviet Union. This relationship between Vietnam and other foreign countries is shown in Table 1.

Table 1

History of Vietnam's Participation in Organizations Around the World

\begin{tabular}{|l|l|}
\hline Time & Organization \\
\hline September 15, 1976 & International Monetary Fund (IMF) \\
\hline September 21, 1976 & The World Bank (WB) \\
\hline September 23, 1976 & Asian Development Bank (ADB) \\
\hline September 20, 1977 & United Nations Security Council \\
\hline June 29, 1978 & Council for Mutual Economic Assistance \\
\hline
\end{tabular}

Resulting from the characteristics of Vietnam's political situation at this stage, Vietnam's socio-economy has changed dramatically.

The economic foundation of the proletarian dictatorship system was the centrally subsidized, planned economy. It was an economy that targets at four main purposes as follows: (1) firstly, eliminating private ownership quickly and completely; (2) secondly, setting the socialist public ownership in two forms: state ownership and collective ownership; (3) thirdly, thoroughly removing market mechanisms; and (4) lastly, establishing the management system of the centrally subsidized, planned economy. The state became a dominating economic organization and did not accept the fact that one economy had many components (Ministry of Education and Training, 2009). State economy continued to hold the leading roles, and families' economic sector was encouraged to increase social products to meet the needs of society (Dang, 2008).

Vietnam's economy in the period of 1975-1985 was operated under the old economic model in accordance with the centrally subsidized mechanism. Socialist reforming process performed at a high level and expanded throughout the country, leading to the early elimination of capitalist economic sectors and individual economic sector. This centrally subsidized mechanism of the economy came with many weaknesses which resulted in the major drag on economic growth and social development as well as brought up with obstacles for the people at this time (Nguyễn, 2004).

The Vietnamese accounting system in this period performed only one mission as the control tool of the state, mainly provided with monitoring information. For the first phase of this period, the units were under the control of the state, so the users of accounting information were management agencies under the Ministry of Finance, Planning Department, and Statistics Departments.

At this point of time, the accounting system aimed to protect and use the assets (including fixed assets and current assets by the state and the proceeds of the enterprise itself). The accounting system was based on Decree 93: State Enterprises Charter issued by the Government on April 18, 1977. The operation of the economy was mainly conducted. Therefore, the financial statement system was enacted rigidly and mainly served the state agencies. Financial statement system was applied uniformly by Decision 223-CP of December 1, 1970: The Financial Statement System. As a result, accounting information provided relied completely on the requirements and regulations of state agencies. Due to the poor, self-sufficient economy, the requirements for accounting information were limited, only monitoring, and not fully developed to its responsibilities. 


\section{Renewal Period of 1986-1990}

Entering 1986, Vietnam's economy was in crisis, as the production was not good enough for society and the economy did not grow. Thus, the trend of innovation was becoming increasingly urgent and expected by the whole country.

Vietnam Communist Party had acknowledged the existence of economies with multiple structural components. In particular, the non-state and collective sectors were recognized and began to receive the support of operating conditions. The economy gradually became market-oriented and began to make positive changes. From the place to import rice, Vietnam had self-sufficient production, reserved and even has been restrained gradually (Online Newspaper of Communist Party of Vietnam, 2006). When the economy is undergoing profound changes, the objects using accounting information have increased, leading to the need of providing accounting information for these objects. The management and supervision of the economy have made a big change.

However, the state sector still plays the leading roles. The information is presented in the financial statements in order to meet the management demand and mainly for evaluation and supervision of the state enterprise while serving for statistics, economic information.

As of 1988, due to the renewal of economic mechanisms, these units had been divided into various types. Each of these types had its own regulations and users of information. Users of accounting information have expanded and diversified more than before.

Table 2

The Legal Accounting System of Vietnam Issued in the Renewal Period

\begin{tabular}{|l|l|l|l|}
\hline Timing & Place issued & Document issued & Content \\
\hline May 1988 & State Council & Ordinance on Accounting and Statistics & $\begin{array}{l}\text { Common principles and international } \\
\text { standards on Vietnam accounting are } \\
\text { acknowledged by Finance Ministry and } \\
\text { National Statistics Agency towards business } \\
\text { enterprises with foreign investment. }\end{array}$ \\
\hline December 1989 1989 & Government & $\begin{array}{l}\text { Ministry of Finance } \\
\text { The Charter on Organization of the State } \\
\text { Accounting } \\
\text { 2. Decree No. 26/HDBT: Chief Accountant's } \\
\text { Role in State-Owned Enterprises }\end{array}$ & $\begin{array}{l}\text { leneral regulations. } \\
\text { The contents of accounting practice. } \\
\text { Regulations on accounting ethics. } \\
\text { Regulation of the chief accountant } \\
\text { position, responsibilities, rights, and } \\
\text { obligations. } \\
\text { Regime for the chief accountant. }\end{array}$ \\
\hline April 1990 & Ministry of Finance & Decision 224/QD/CDKT (18/4/1990) & $\begin{array}{l}\text { The system of accounting documents. } \\
\text { The system of single accounting account. } \\
\text { The system of accounting records. } \\
\text { Accounting statements system. }\end{array}$ \\
\hline December 1990 & Ministry of Finance & $\begin{array}{l}\text { The regime of periodic accounting } \\
\text { statement for the uniform application of } \\
\text { state-owned industrial enterprises. }\end{array}$ \\
\hline Decision 598/QD/CDKT (12/1990) & $\begin{array}{l}\text { The regime of production accounting, } \\
\text { business private-owned enterprises. }\end{array}$ \\
\hline
\end{tabular}

The first change in this period was dated March 18, 1989, when the government signed the Decree No. 25/HDBT of March 18, 1989: The Charter on Organization of the State Accounting replacing the Government Decree 157 in 1961. The aim of the Decree No. 25 is to maintain a single accounting system for the industry and sector. Also at this time, Decree No. 26/HDBT: Chief Accountant's Role in State-Owned 
Enterprises was issued by the Government on March 18, 1989. This is firstly regulated on accounting ethics, provisions of the chief accountant position, responsibilities, rights, and obligations, and chief accounting regime. These statements provide information related to the fluctuation of the equity, consumption situation and business results, and the distribution of income in the economic bodies outside the state. The legal accounting system of Vietnam issued in this period can be seen in Table 2.

So, at this stage, there had been a step of change, i.e., perceptions and contents of accounting operations and accounting systems had transferred from accounting served for state economic management of the centrally planned economy to market economy. Moreover, the accounting profession had been established, while the roles, position, and authority of the chief accountant had been enhanced. Chief accountants had gained satisfactory positions in management system. The club of chief accountants was founded nationwide.

In summary, right after Vietnam was liberated, due to the characteristics of the economy, the information on the financial statements for the period was presented with 13 indexes, divided into four categories, mainly served for state management. Then, after economic reforms in 1986, this system was amended in accordance with the economic change as well as users of accounting information.

\section{Characteristics of the Political System in the Reform Period (1989-2003)}

The view of the Communist Party leaders in this phase was to incorporate tightly the economic reform with political reform. Particularly, most attention was paid to economic reform. On the basis of accepting the existence of market economy, accounting systems were also added and adjusted in accordance with the actual requirements. Accordingly, the accounting system in this period also changed profoundly with a purpose of serving the integration in the world economy of Vietnam. In fact, the Ministry of Finance issued Circular 84-TC/CDKT 23-10-1993: Guiding the Implementation of Accounting Activities in Foreign-Invested Enterprises, guiding the implementation of accounting for enterprises with foreign investment and foreign parties to the contract of business cooperation activities under different forms.

Besides, resulting from the requirements of the innovation process of accounting systems in order to meet the requirements of state businesses and other types of businesses, Decision No. 1141-TC/QD/CDKT of November 1, 1995 promulgating the enterprises' accounting regime had been issued. One year later, based on this accounting regime, the Ministry of Finance built up another new accounting regime (Decision No. 1177/TC/QD/CDKT of December 23, 1996) for small and medium entities.

Accounting Regime 1141 was the first one to indentify clearly and create accounting information to meet the demand of internal and external stakeholders. In addition, the advent of the Vietnam Accounting Association (VAA) on October 1, 1994 recognized the presence of accounting and the professional accounting profession in Vietnam. After two years, VAA became a member of the International Federation of Accountants (IFAC) and until 1998 was a member of the ASEAN Federation of Accountants (AFA). These events marked an important step in the integration process and the international recognition of the accounting profession in Vietnam.

The process of globalization has put pressure on Vietnam to reform the accounting system to be in harmony with international standards. The pressure of the international organizations and donors requires the Government of Vietnam to supply and allow access to a complete legal system, including the accounting field. Therefore, problems in harmony with international practices are set out as an official requirement of the accounting system reform. 


\section{Period of 2003-2015}

\section{Political Institutions}

In the years from 2003 to 2013, political institutions have been virtually stable in a single model. The political system of Vietnam from 2003 to 2015 has been organized in the model of nation's rule of law. Vietnamese economy has experienced significant changes. Based on the development of economic components, Vietnam has accessed to foreign markets. During this stage, export turnover grew sharply due to areas of foreign investment. The major export markets of Vietnam during this period were the US, EU, ASEAN, and Japan. In addition, the total amount of investment increased by an average of $13.8 \%$ per year. Much of the investment development has been financed by government bonds. Apart from government investment, foreign investment plays an important role in the total investment in social development. Taiwan, Korea, and Singapore are the largest investors in this period.

Especially, Vietnam accounting has developed quickly and strongly on both quality and quantity. It has formed a team of accountants with high skills. Markets of financial and accounting services have gradually developed contributing to economic growth and responding effectively to the process of international integration. The legal system of Vietnamese accounting was built and completed on the basis of access to international standards, in accordance with the requirements of the market economy. The legal system of corporate accounting of Vietnam is classified into three levels: accounting law and the decrees, accounting standards system and regulations, and accounting regime.

\section{Accounting Law (2003)}

Accounting Law No. 03/2003 issued by the National Assembly so far has gone into practical operation of the economy, paving the way for legal provisions to be born. It also had a positive impact on economy and society. Accounting Act 2003 includes seven chapters with 64 articles.

\section{Accounting Standards}

During this period, the Ministry of Finance had issued 26 accounting standards on the basis of applying the principles of international accounting standards in accordance with the situation and characteristics of Vietnam, setting the stage for the development of institutional accounting applied to specific objects.

Some shortcomings in the implementation process of the Vietnam accounting legal system. The renewal of the country's economy and international integration process is not only to create long-term opportunities and advantages but also to pose challenges for macro-economic management in general and accounting activities. Besides the initial results achieved during the operation of the accounting legal system, certain limitations were also revealed:

(1) First of all, the Accounting Law (2013) has revealed many features which no longer fit the reality. Even though it has been the top legal basis of Vietnam accounting legal system over 10 years of operations, regulations and contents of accounting in this period have been applied only for separate accounting units, which no longer fit the recent market economy in Vietnam where there have been a lot of large-sized businesses operating in multiple industries, dimensions, and countries;

(2) Second, there exist gaps in the system of accounting standards:

(a) The first gap is that accounting principles have not been fully applied; 
(b) The second gap is that accounting standard system is incomplete, causing difficulties in handling the economic transactions arising in practice. Besides the 26 Vietnam accounting standards issued, there is still a lack of many essential criteria;

(c) The third gap is that there exists a lack of updates and content differences between Vietnam accounting standards and international accounting standards. Since 2001, international accounting standards have been repeatedly amended and innovated. The amendments were carried out in accordance with the actual situation to ensure the transparency of the consolidated financial statements.

(3) Third, there is a lack of flexibility of enterprise accounting regime: Currently, there exists a dual-regime applied for business accounting: accounting regime now issued under Decision No. 15/2006/QD-BTC: Promulgating the Business Accounting Regime used for all types of businesses and accounting regime for small and medium enterprises issued under Decision 48/2006/QD-BTC (Accounting for Small and Medium Enterprises). The Decision 48/2006/QD-BTC was originally identified as suitable for the market economy, in line with international practice of accounting, in accordance with economic characteristics and managerial skills of small and medium enterprises. Instead, the majority of businesses are applying accounting regime under Decision No. 15. Furthermore, the determination of the size of the business is not accurate, leading to the fact that there appears to be an overlap when selecting accounting regulations to be applied;

(4) Fourth, there are too many regulations on accounting, and they are unsystematic;

(5) Fifth and last, there are also gaps between accounting standards and guidance circulars. In fact, some guidance circulars nullify the content specified in the standards and then produce disagreements in the implementation. This, therefore, affects the credibility of the investors on a consistent method of Vietnam accounting.

The accounting and auditing orientation to the year 2020 is that by 2020, Vietnam will have had a full integration in the field of international accounting and auditing (Accounting Strategy Audit 2020, Vision 2030).

In particular, the period of 2006-2010 was the consolidation phase of integration. The period of 2010-2020 is the period of dynamic integration. Vietnam will have integrated comprehensively, equally with other countries in the field of accounting and audit. We offer both imports and exports of accounting and auditing services. In the process of joining the WTO, Vietnamese Government is committed to the donors and international organizations to reform Vietnamese accounting system in which Vietnam has committed to perfecting a system of complete accounting standards and in accordance with international accounting regulations. Therefore, to achieve the objectives of the above orientations, it is imperative that Vietnam come with international accounting convergence. Methods of convergence and convergent process are a big challenge. There are several issues to be considered to find out answers to this question.

\section{Factors Affecting the Process of International Accounting Convergence}

Vietnam is being affected by political, economic, and cultural factors.

\section{Political Factors}

The process of forming Vietnam accounting standards shows the will of Vietnamese Government in the process of global economic integration to achieve its political and economic targets. According to Nguyen and Richard (2011), Vietnam had issued accounting standards arising from the pressure to be accepted as a member of the WTO with the starting point of almost zero. 


\section{Economic Factors}

Vietnam is a developing country. Although the government aims to diversify its economic sectors, state economy takes leading roles in economic development. Vietnam financial markets recently have changed positively. During the period of 2000-2005, the market capitalization approximately accounted for $1 \%$ of GDP to $22.7 \%$ in 2006 and continued to achieve above $43 \%$ of GDP recorded in 2007 . Then, due to the world economic crisis, the capitalization of the year decreased in several years later. However, in 2013, the market capitalization increased, with 199 trillion USD higher than that of 2012, equivalent to 31\% of GDP (Vu Trong, 2013). The rise of the indexes had enabled Vietnam stock market to become one of the 10 countries with the fastest recovery of the world. This led to the fact that more and more domestic and foreign investors require rationale information to meet the needs of decision-making. This means that the accounting standards must be standardized in parallel with the system of international accounting standards.

\section{Cultural Environment}

Vietnam's cautious culture causes Vietnam to have difficulty in accepting series of new concepts of International Financial Reporting Standards (IFRS) as a rationale value. In other words, with 26 standards issued, Vietnam has applied most of these which are in accordance with Vietnam culture. As a result, there have been many challenges to the adoption of the aforementioned remaining contents of the practices in Vietnam. The background of Vietnam economy in the trend of international accounting convergence was indicated as follows:

(1) Export of Vietnam: Exporting plays a crucial role in Vietnam's economy. Vietnam's export has made a strong growth thanks to the economic innovation. From 1986 to 1990, the export value of Vietnam increased threefold, reaching 2.4 billion USD, by 2002 increased by 16 billion USD, and by the end of 2012, it had reached 114.57 billion USD, reaching 18.2\% compared to 2011 (Vietnam General Customs, 2013). Hence, to be recognized as a market economy sooner, it is a must for Vietnam to meet the requirements of the convergence of accounting with IFRS;

(2) Vietnam stock market: Vietnam stock market has developed rapidly in recent years despite a decline in the past years. According to a scheme approved by the state government, the target is set to 2020; market capitalization will have reached $70 \%$ of GDP and will have had a diversification of supply services (Government, 2007). In this context, the convergence of accounting standards with international financial statements is essential in order to attract foreign investment, protect investors, and protect the economy;

(3) Foreign direct investment: Foreign investment is a powerful factor in promoting the innovation of Vietnamese accounting system. Enterprises having abroad investment must apply Vietnamese accounting system and must additionally set up financial statements in accordance with the accounting standards used by parent companies, which has increased their incurred costs;

(4) Mergers and acquisitions: Mergers and acquisitions are an important tool in developing the scope and operation of the business. In Vietnam, the value of average annual sales in the period of 2005-2007 was 150 million USD, then reached 1,126 million USD in 2011, and was 908 million dollars until 2012 due to the global recession (United Nations Conference on Trade and Development [UNCTAD], 2013). The convergence of accounting helps this process take place more effectively; 
(5) Listed on foreign stock markets: Currently, government policy has paved the way for domestic companies to be listed on international stock markets. This is a crucial distribution channel for raising the capital of Vietnam businesses. In order to prepare for this process, Vietnam businesses need an access to the preparation of financial statements in accordance with IFRS (Thinh, 2014);

(6) Market of accounting and auditing services: According to the commitment of Vietnam when joining the WTO, businesses operating in Vietnam can use not only unlimited foreign accounting and auditing services but also unrestricted foreign investment in this sector (WTO, 2006). The convergence of accounting enables Vietnam to be more proactive in developing human resources and enhancing its participation in the world market.

\section{The Orientation of the Way of Convergence}

Starting from an analysis of the factors affecting the process of convergence of international accounting and Vietnam economic context in the trend of international accounting convergence, Vietnam has to choose a rationale method of the convergence of international accounting in accordance with the socio-economic circumstances. Presently, there are three basic ways of convergence. They are:

(1) Whole convergence: All nations accept all IFRS without any adjustments. Its pros are that this method will save considerable cost and time for the national draft. The governments will have to modify the legal frameworks as well as the drafting of guidelines to suit IFRS and ensure information transparency and quality for financial statements of businesses, creating opportunities to access international capital markets. However, its cons are that differences in legal environment have formed the characteristics of the national accounting system. Therefore, the appliance of this accounting system seems to have difficulties. Vietnam is an example. The differences in languages are an important limitation in the application of IFRS to all kinds of businesses;

(2) Asymptotical convergence: The countries will not accept all the standards of international financial statements, but have additions and adjustments to the current systems to make them similar to the IFRS in a certain way. Applying this method produces advantages such as making less disturbance or fewer arguments as to protecting the most the uniqueness of a nation in the process of convergence, no language barriers in metabolism, no requirements for high accounting qualifications and experience, and avoiding current difficulties in this period. Nevertheless, international accounting standards have consciously changed, causing problems for nations who have not participated in building up IFRS. For example, adjusting frequently the accounting system due to the frequent change of international financial statements leads to high-incurred costs in updating and avoiding being backward. In some cases, national accounting standard systems are judged as inferior to the level of convergence, causing low confidence to investors;

(3) Intermediate convergence: The application of the standards of international financial statements appears in some objects. Other objects apply the national accounting standards adjusted in accordance with international financial statements parallel with the specific characteristics of the country. The pros are: meeting the trend of the convergence of international accounting; improving the quality of information and facilitating economic development; and avoiding fluctuations for small and medium businesses. The cons are: there are still certain pressures on the convergence of international accounting; partly impacting on listed companies; and objects are required to apply international financial statement standards. Stemming from the findings of the research from 2008 to date, Vietnam cannot converge wholly or asymptotically, but should converge intermediately because of the following reasons: 
In case of the whole convergence:

(1) English is not the primary language of Vietnam;

(2) Professional organizations in Vietnam are still young. The number of the members is not high and just stops at the level of attendance rather than participation in the formulation activities in and outside the country;

(3) Vietnam's stock markets are not strong enough to become the main stimulator for the whole convergence.

In case of asymptotical convergence:

(1) It takes a lot of time to change gradually standards;

(2) Facing with the risk of being outdated all times;

(3) The gap between IFRS and national standards is quite big.

In the opinion of the author of this paper, that Vietnam selects the method of intermediate convergence is reasonable because of the following factors:

(1) Vietnam has experience in the construction of national accounting standards in accordance with IFRS, operating alongside corporate accounting regime;

(2) The weaknesses of Vietnam, such as accounting qualifications, legal characteristics, cultural environment, etc., will be restricted when accessing to two parallel standard systems. They also give a chance of time and internal resources for businesses which are not able to afford IFRS to approach incrementally IFRS.

\section{Conclusion}

In summary, in the current economic context, Vietnam's international accounting convergence is essential for economic development in many areas, increasing its competitiveness in the international markets in a variety of fields. At the same time, the convergence has indicated that Vietnam has become more active in its deeper integration with the world economy, undertaken multilateral relations of Vietnam with the countries of the world, signaled acceptance of international economic integration, and participated in the global capital markets.

\section{References}

Dang, P. (2008). Vietnam economic thinking: The spectacular way, 1975-1989. Hanoi.

Government. (2007). Quyết định số 128/2007/QĐ-TTG của Thủ tuớng Chính phủ: Về việc phê duyệt đề án phát triển thị truờng vốn Việt Nam đến năm 2010 và tầm nhìn đến năm 2020.

Ministry of Education and Training. (2009). Curriculum revolution way of communist party of Vietnam. Hanoi.

Nguyễn, C. H. (2004). Lịch sủ kinh tế quốc dân. TP.HCM: NXB Đại học Quốc Gia TP.HCM.

Nguyen, C. P., \& Richard, J. (2011). Economic transition and accounting system reform in Vietnam. European Accounting Review, 20(4), 693-725.

Online Newspaper of Communist Party of Vietnam. (2006). Retrieved from http://dangcongsan.vn/cpv/Modules/News/NewsDetail.aspx?co_id=30623\&cn_id=197979

Thinh, Q. T. (2014). Định hướng xây dựng chuẩn mục báo cáo tài chính Việt Nam đáp ứng xu thế hội tu kế toán quốc tế.

United Nations Conference on Trade and Development [UNCTAD]. (2013). World investment report 2013. Global value chains: Investment and trade for development. Retrieved from http://unctad.org/en/PublicationsLibrary/wir2013_en.pdf

Vietnam General Customs. (2013). Sobộ tình hình xuất khẩu, nhập khẩu hàng hóa của Việt Nam.

$\mathrm{Vu}$ Trong. (2013). Securities: Market capitalization 2013. Retrieved from http://baodientu.chinhphu.vn/Kinh-te/Chung-khoan-Muc-von-hoa-thi-truong-2013-dat-31-GDP/188830.vgp

WTO. (2006). Biểu cam kết cu thể về dịch vụ: Danh mục miễn trù đối xủ tối huệ quốc theo điều II. 